\title{
Identification of cdtB homologues and cytolethal distending toxin activity in enterohepatic Helicobacter spp.
}

\author{
CHIH-CHING CHIEN*, NANCY S. TAYLOR*, ZHONGMING GE*, DAVID B. SCHAUER*†, VINCENT \\ B. YOUNG $\dagger$ and JAMES G. FOX*广
}

* Division of Comparative Medicine and †Division of Bioengineering and Environmental Health, Massachusetts Institute of Technology, Cambridge, MA 02139, USA

\begin{abstract}
A bacterial toxin that causes progressive distension and death of Chinese hamster ovary (CHO) cells and HeLa cells, termed cytolethal distending toxin (Cdt), has been identified in several diarrhoeagenic bacteria, including Campylobacter spp. (C. jejuni and $C$. coli), some pathogenic strains of Escherichia coli and Shigella spp. Genes encoding this toxin were identified as a cluster of three adjacent genes $c d t A, c d t B$ and $c d t C$. Homologues of cdtB from five species of enterohepatic helicobacters (Helicobacter hepaticus, $H$. bilis, $H$. canis and two novel Helicobacter spp. isolated from mice and woodchuck, respectively) were identified by means of degenerative PCR primers, cloned and sequenced. The similarities of these partial $c d t B$ nucleotide sequences from these Helicobacter spp. to those of $c d t B$ genes known to be present in other bacteria were: $C$. jejuni, 58.3-64.8\%; E. coli, 52.3-57.8\%, Haemophilus ducreyi, 53.4-58.4\% and Actinobacillus actinomycetemcomitans, 52.7-58.1\%. Bacterial lysates from four of these helicobacters caused characteristic cytolethal distension of HeLa cells. Cdt caused cell cycle arrest at $\mathbf{G}_{2} / \mathbf{M}$ phase as measured by flow cytometry. The results demonstrated the presence of a toxin in these Helicobacter spp. belonging to the family of $\mathrm{Cdt}$.
\end{abstract}

\section{Introduction}

An increasing number of gastrointestinal Helicobacter spp. has been isolated since the recognition of $H$. pylori as a causative agent of active, chronic gastritis and peptic ulcer disease $[1,2]$, as well as the bacterium's strong association with the development of gastric adenocarcinoma and gastric mucosa-associated lymphoma [3-5]. Several novel Helicobacter spp. cause persistent hepatitis and inflammatory bowel disease (IBD) in different strains of mice [6-14]. Novel enterohepatic helicobacters have also been isolated from inflamed colonic tissue of cotton-top tamarins [15] and man [16,17], as well as from diseased livers and intestines of several other mammals [18-20]. Enterohepatic Helicobacter spp. have also been identified recently in bile and gall bladder tissue from patients with chronic cholecystitis [21]. However, little is known about virulence factors of these newly discovered bacteria and pathogenic mechanisms involved in inducing gastrointestinal diseases.

Received 27 July 1999; revised version received 5 Nov. 1999; accepted 6 Nov. 1999.

Corresponding author: Dr J. G. Fox (e-mail: jgfox@mit.edu).
A bacterial toxin that causes progressive distension and death of Chinese hamster ovary $(\mathrm{CHO})$ cells, termed cytolethal distending toxin (Cdt), was first described by Johnson and Lior [22] in an enteropathogenic strain of Escherichia coli [22]. Toxins belonging to this group were later identified in several other diarrhoeagenic bacteria, including Campylobacter spp. (C. jejuni, C. coli and $C$.fetus) $[23,24]$, and other pathogenic strains of $E$. coli [25-28] and Shigella spp. [29]. Cdt was also found in non-enteric pathogenic bacteria such as Haemophilus ducreyi [30] and Actinobacillus actinomycetemcomitans [31]. Genes encoding this toxin were identified as a cluster of three adjacent genes $c d t A, c d t B$ and $c d t C$, and produce proteins of $c$. 28,30 and $20 \mathrm{kDa}$, respectively [26, 27]. Studies in A. actinomycetemcomitans suggested that all three proteins, $\mathrm{CdtA}, \mathrm{CdtB}$ and $\mathrm{CdtC}$, are required for the function of the toxin [31, 32]. These genes have been cloned and sequenced from a number of bacteria including E. coli [26-28], S. dysenteriae [29], C. jejuni [24], H. ducreyi [30] and A. actinomycetemcomitans [31]. In C. jejuni, $c d t$ encodes proteins of 268,265 , and 189 amino acids (aa), respectively. Cdts from E. coli, $C$. jejuni and $A$. actinomycetemcomitans are known to inhibit cell cycle progression by arresting cells in the $\mathrm{G}_{2} / \mathrm{M}$ phase $[27,31,33,34]$. 
Because many Helicobacter spp. can cause intestinal diseases in their natural hosts, an earlier study investigated whether or not Cdt was also present in enterohepatic Helicobacter spp.; if present, this would help explain the adverse effect of these bacteria on host tissue. Recently, Cdt in H. hepaticus and H. pullorum was partially characterised [35]. This report confirms and extends these findings, - it describes the cloning and sequencing of partial $c d t B$ homologues from five species of enterohepatic helicobacters ( $H$. hepaticus, H. bilis, H. canis and two newly described Helicobacter spp. isolated from mice and woodchucks, respectively) by degenerative PCR primers. It also examined the cytotoxic effects of bacterial lysates on HeLa cell morphology and replication.

\section{Materials and methods}

\section{Bacterial strains and cultivation}

All strains were obtained from the Division of Comparative Medicine culture collection at Massachusetts Institute of Technology: $H$. hepaticus 3B1 (ATCC51449) [6], H. bilis (ATCC51630 $)$ [8], H. canis $\left(\mathrm{ATCC} 51401^{\mathrm{T}}\right.$ ) [36], H. pylori (NCTC11639) and C. jejuni 81-176 [37]. Helicobacter sp. strain 961001 was a novel urease-negative helicobacter isolated from a mouse and induced IBD and cholecystitis experimentally in mice [38]. Helicobacter sp. strain 98-6070 was isolated from woodchuck livers infected with hepadnavirus [20]. Helicobacter spp. were grown on Columbia blood agar (sheep blood 5\%; Remel) plates or in Brucella broth supplemented with bovine calf serum $5 \%$ and incubated under micro-aerobic conditions in vented jars (by replacing the head space once with a gas mixture containing $\mathrm{H}_{2} 10 \%, \mathrm{CO}_{2} 5 \%$, and balanced with $\mathrm{N}_{2}$ ) at $37^{\circ} \mathrm{C}$ for $3-5$ days. E. coli strain JM109 (Promega, Madison, WI, USA) was used as a host for the plasmid harbouring the genes of interest and grown in LB broth supplemented with ampicillin $50 \mu \mathrm{g} / \mathrm{ml}$ when appropriate.

\section{DNA extraction and PCR amplification}

Bacterial cells were harvested from agar plates, washed twice with $1 \mathrm{ml}$ of PBS and then collected by centrifugation at $8000 \mathrm{~g}$. DNA was extracted from cell pellets of H. pylori, H. hepaticus, H. canis, H. bilis, Helicobacter sp. strain 96-1001, Helicobacter sp. strain 98-6070 and C. jejuni 81-176 with a commercial kit (High Pure PCR Template Preparation Kit, Boehringer Mannheim) according to the manufacturer's instructions.

Oligonucleotide primers were purchased from Integrated DNA Technologies (Coralville, IA, USA). Degenerative primers VAT2 (forward, 5'-GTNG CNACBTGGAAYCTNCARGG-3') and WMI1 (reverse, 5'-RTTRAARTCNCCYAADATCATCC-3') were designed as described by Pickett et al. [24]. Another degenerative primer designated DHF1 was designed (reverse, 5'-DACNGGRAARTGRTC-3') which was deduced from the amino acid sequence DHFPV (amino acids 256-260 derived from the $c d t B$ gene of $C$. jejuni) [24]. With these degenerative primers, the PCR assay used a $100-\mu 1$ reaction mixture containing $5 \mu \mathrm{l}$ of the DNA preparation, $1 \times$ Taq polymerase buffer (provided by the manufacturer but supplemented with $\mathrm{MgCl}_{2}$ $1 \mathrm{~mol} / \mathrm{L}$ to a final concentration of $2.25 \mathrm{mmol} / \mathrm{L}$ ), $0.5 \mu \mathrm{M}$ of each forward and reverse primer, $200 \mu \mathrm{M}$ of each deoxynucleotide (ddATP, ddGTP, ddCTP and ddTTP), bovine serum albumin $20 \mu \mathrm{g}$ and Taq polymerase (Boehringer Mannheim) $2 \mathrm{U}$. The thermocycling programme consisted of 35 cycles of $94^{\circ} \mathrm{C}$ for $1 \mathrm{~min}, 42^{\circ}$ for $2 \mathrm{~min}, 72^{\circ} \mathrm{C}$ for $3 \mathrm{~min}$, followed by incubation at $72^{\circ} \mathrm{C}$ for $8 \mathrm{~min}$ for elongation.

\section{Cloning and nucleotide sequence determinations}

PCR amplicons of expected sizes (494 bp from VAT2 and WMI1 and $714 \mathrm{bp}$ from VAT2 and DHF1, respectively) were purified with QIAEX II (Qiagen, Studio City, CA, USA) from low melting point agarose (1\%) gel. The purified DNA fragments were subsequently cloned into a vector pGEM $^{\mathbb{R}}$-T Easy (Promega) and then transformed into competent $E$ coli cells provided by the same company, according to the manufacturer's instructions. Recombinant plasmid clones were selected on LB agar plates supplemented with ampicillin $50 \mu \mathrm{g} / \mathrm{ml}$, Xgal $80 \mu \mathrm{g} / \mathrm{ml}$ and $(0.5 \mathrm{mM})$ IPTG. Plasmid DNA was isolated from transformed $E$. coli cells by an alkaline lysis procedure [39]. Cloned inserts (both strands) were sequenced with a thermocycling sequenase kit purchased from Amersham Life Science, (Cleveland, OH, USA) following the procedures provided by the supplier's manual. These pGEM $^{\circledR}$-T recombinant plasmids with DNA inserts from Helicobacter spp. in E. coli - $\mathrm{pHH} 1$ (from $H$. hepaticus), $\mathrm{pHB} 2$ (from $H$. bilis), $\mathrm{pHC} 1$ (from $H$. canis), pHM2 (from Helicobacter sp. strain 96-1001) and pHWC4 (from Helicobacter sp. strain 98-6070 - were sequenced.

\section{Southern hybridisation}

Southern hybridisation was conducted to confirm the origin of the PCR-amplified $c d t B$ homologues. Chromosomal DNA samples $(\sim 5 \mu \mathrm{g})$ of $H$. hepaticus, $H$. bilis, H. canis, Helicobacter sp. strain 96-1001 and Helicobacter sp. strain 98-6070 were digested with Ase I and HindIII, electrophoretically separated on to an agarose $1 \%$ gel and then transferred on to a Hybond $\mathrm{N}$ nylon membrane according to the manufacturer's protocol (Amersham, Arlington Heights, IL, USA). Membrane-bound DNA was UV cross-linked and then hybridised with probes prepared from one of the recombinant plasmids containing Helicobacter spp. $c d t B$ DNA. Southern hybridisation procedures were employed with ECL ${ }^{\mathrm{TM}}$ direct nucleic acid labelling and detection systems with the standard procedure accord- 
ing to the manufacturer's instructions (Amersham Life Science). Low-stringency hybridisation was performed with $\left[\alpha-{ }^{32} \mathrm{P}\right] \mathrm{dCTP}-$ labelled probe in the nick translation system (BRL). The membrane was pre-hybridised in a buffer $(5 \times \mathrm{SSC}$, formamide $50 \%$, denatured salmonsperm DNA $100 \mu \mathrm{g} / \mathrm{ml}, 0.001 \mathrm{M}$ EDTA and $1 \times$ Denhardt's solution) at $37^{\circ} \mathrm{C}$ for $1 \mathrm{~h}$. Denatured ${ }^{32} \mathrm{P}$ labelled probe was added to the prehybridisation solution and the membrane was incubated at $37^{\circ} \mathrm{C}$ overnight. The membrane was washed twice in a solution of $2 \times \mathrm{SSC}$ and sodium dodecyl sulphate (SDS) $1 \%$ at $37^{\circ} \mathrm{C}$ for $1 \mathrm{~h}$ and exposed at $-80^{\circ} \mathrm{C}$ overnight.

\section{Analysis of nucleotide sequences and sequence accession numbers}

The partial sequences of $c d t B$ genes of Helicobacter spp. obtained from this study were compared with the DNA and amino-acid sequences available in the public databases. Nucleotide and protein sequences were analysed with the DNA Lasergene software package (DNA Star, Madison, WI, USA). The Genbank accession numbers for the nucleotide sequence data of the $c d t$ genes used and presented in the study are: $E$. coli, U04208 [26]; E. coli, U03293 [27]; C. jejuni, U51121 [24]; A. actinomycetemcomitans, AB011405; H. ducreyi, 53215; H. bilis, AF243077; H. hepaticus, AF243076; H. canis, AF243078; Helicobacter sp. strain 96-1001, AF243080; Helicobacter sp. strain 98-6070, AF243079.

\section{Cytolethal distending toxin assay}

Preparation of cell sonicates. Bacteria were grown in Brucella broth containing fetal calf serum 5\% with shaking at $100 \mathrm{rpm}$, or on Columbia blood agar sheep blood 5\%, Remel) plates, under micro-aerobic conditions and incubated for 4 days. Cells were harvested at $4^{\circ} \mathrm{C}$ by centrifugation at $10000 \mathrm{~g}$ (Sorval RC5B). The pellet was washed once with PBS and then resuspended to $1 \mathrm{ml}$ in PBS. The pellet was sonicated on ice with four 30-s pulses at a setting of 20 with an Artek sonic dismembrater Model 150. The sonicate was centrifuged at $8000 \mathrm{rpm}$ and the supernatant fraction was filtersterilised with a $0.22-\mu \mathrm{m}$ filter. Samples were stored at $-70^{\circ} \mathrm{C}$ until tested.

Tissue-culture assay for morphological changes by $C d t$. One $\mathrm{ml}$ of HeLa cells at $10^{3}$ cells $/ \mathrm{ml}$ of EMEM (Minimum Essential Medium Eagle with Earle's salts; Sigma, fetal calf serum (Summit Biotechnology, Fort Collins, CO, USA) $10 \%$ were seeded into wells on $24-$ well plates. After incubation for $3 \mathrm{~h}$ at $37^{\circ} \mathrm{C}$ in an atmosphere of $\mathrm{CO}_{2} 8 \%$ in air, $10 \mu \mathrm{l}$ of filter-sterilised supernate of cell sonicate were added to each well. Plates were re-incubated and observed daily for 3 days. After $72 \mathrm{~h}$, the wells were washed with phosphatebuffered saline, stained with Diff-Quick Stain (Dade
International, Miami, FL, USA), and observed microscopically.

\section{Flow cytometry methods}

Tissue-culture flasks $\left(25 \mathrm{~cm}^{2}\right)$ were seeded with $5 \mathrm{ml}$ of EMEM-fetal bovine serum $10 \%$ at $1 \times 10^{5} \mathrm{HeLa}$ cells $(\mathrm{CCL}-2) / \mathrm{ml}$. Flasks were inoculated with $100 \mu \mathrm{l}$ of filter-sterilised bacterial sonicate and then incubated at $37^{\circ} \mathrm{C}$ with $\mathrm{CO}_{2} 8 \%$ for $72 \mathrm{~h}$. The cells were detached by treatment with $0.5 \mathrm{ml}$ of trypsin $0.5 \%$-EDTA $0.2 \%$ for 3-5 min. Cells were transferred to a $1.5-\mathrm{ml}$ microfuge tube and pelleted at $3000 \mathrm{rpm}$ for $3 \mathrm{~min}$ in a Heraeus Instruments Biofuge (VWR). The pellets were gently resuspended in $1 \mathrm{ml}$ of stain solution (PEG-8000 3\%, propidium iodide $4 \mu \mathrm{g} / \mathrm{ml}$, RNAase A $9 \mathrm{U} / \mathrm{ml}$, Triton-X $1000.1 \%$, bovine serum albumin $0.0001 \%$ in $4 \mathrm{~mm}$ sodium citrate) and then incubated at $37^{\circ} \mathrm{C}$ for $20 \mathrm{~min}$. One $\mathrm{ml}$ of salt solution (PEG 3\%, propidium iodide $4 \mu \mathrm{g} / \mathrm{ml}$, Triton-X $1000.1 \%$, bovine serum albumin $0.0001 \%$ in $0.4 \mathrm{M} \mathrm{NaCl}$ ) was added, the solution was thoroughly mixed, and then stored at $4^{\circ} \mathrm{C}$ for $3 \mathrm{~h}$. DNA analysis was performed on a FACScan flow cytometer (Beckman Dickenson, Franklin Lakes, NJ, USA) with Cell Quant software for data acquisition. The ModFit program was used for data analysis. For each experiment, $1 \times 10^{4}$ cells were analysed.

\section{Results}

Cloning and sequence determination of $c d t B$ homologues from enterohepatic Helicobacter spp.

With primers VAT2 and WMI1 described previously by Pickett et al. [24], PCR amplicons approximating the expected length (494 bp of the $C$. jejuni $c d t B$ ) were produced from the novel urease-negative Helicobacter sp. strain 96-1001 (479 bp) and H. canis (506 bp), but not from $H$. hepaticus, $H$. bilis, Helicobacter sp. strain 98-6070 and $H$. pylori. With degenerative primers VAT2 and DHF1 based on sequences in the conserved region of $C$. jejuni and $E$. coli $c d t B$, it was possible to amplify products of the expected length (714 bp according to the $c d t B$ gene of $C$. jejuni) from all five enterohepatic Helicobacter spp. examined but not from H. pylori. These amplicons were cloned into vector $\mathrm{pGEM}^{\circledR}-\mathrm{T}$ Easy. The sizes of the inserts from respective recombinant plasmids were as follows: $738 \mathrm{bp}$ (246 aa) in pHH1 for $H$. hepaticus; $738 \mathrm{bp}$ (246 aa) in pHB2 for H. bilis; 738 bp (246 aa) in pHC1 for $H$. canis; $711 \mathrm{bp} \mathrm{(237} \mathrm{aa)} \mathrm{in} \mathrm{pHWC4} \mathrm{for}$ Helicobacter sp. strain 98-6070 and $693 \mathrm{bp}$ (231 aa) in $\mathrm{pHM} 2$ for Helicobacter sp. strain 96-1001. The similarities of the nucleotide sequences (without primer regions) from these Helicobacter spp. to those known $c d t B$ genes present in other bacteria were in the ranges: C. jejuni, 58.3-64.8\%; E. coli, 53.5-57.8\% [26]; E. coli, 52.3-55.2\% [27]; H. ducreyi, 53.4-58.4\% and $A$. actinomycetemcomitans, 52.7-58.1\%. The nucleotide sequences of the partial $c d t B$ homologues of $H$. 
hepaticus, $H$. bilis and $H$. canis showed more similarity to each other (between 68.9 and $75.3 \%$ ) than to Helicobacter sp. strain 98-6070 (58.1-59.3\%) and the novel urease-negative Helicobacter sp. strain 96-1001 (56.7-59.4\%). Interestingly, the partial $c d t B$ homologues of Helicobacter sp. strain 98-6070 and Helicobacter sp. strain 96-1001 shared 69.2\% similarity. The similarity matrix based on the $c d t B$ nucleotide sequences from these bacteria is shown in Table 1 [40].

Deduced amino-acid sequences of CdtB from $H$. hepaticus, H. canis and H. bilis shared more similarity with each other $(72.2-83.8 \%)$ than with those of Helicobacter sp. strain 96-1001 (53.5-54.4\%) and Helicobacter sp. strain 98-6070 (54.7-57.4\%). Comparison of the predicted amino-acid sequences of $\mathrm{CdtB}$ of the five Helicobacter spp. with that of C. jejuni is shown in Fig. 1. The phylogenetic analysis indicated that CdtB proteins of $H$. hepaticus, $H$. bilis and $H$. canis were clustered in a group, whereas Helicobacter sp. strain 96-1001 and Helicobacter sp. strain 98-6070 were in another cluster (Fig. 2).

\section{Southern blot hybridisation}

A probe prepared from the insert DNA of pHH1 (the $H$. hepacticus $c d t B$ homologue) hybridised with genomic DNA of $H$. hepaticus with the standard procedure provided by $\mathrm{ECL}^{\mathrm{TM}}$. It also hybridised weakly with $H$. bilis and $H$. canis genomic DNA (Fig. 3a). However, the probe prepared from the $H$. hepaticus $c d t B$ homologue did not hybridise with DNA of Helicobacter sp. strain 96-1001 and Helicobacter sp. strain 98-6070. In contrast, the probe prepared from the partial sequence of the $c d t B$ gene from Helicobacter sp. strain 96-1001 hybridised with DNA of Helicobacter sp. strain 96-1001 and Helicobacter sp. strain 98-6070, but not with genomic DNA of $H$. hepaticus, H. canis and H. bilis (Fig. 3b). Lowstringency hybridisation with $\left[{ }^{32} \mathrm{P}\right] \mathrm{dCTP}$ labelled probe gave the same results (results not shown).

\section{Cytotoxic effects of crude cell extracts of Helicobacter spp. on HeLa cells}

The response of HeLa cells exposed for $72 \mathrm{~h}$ to PBS and filter-sterilised supernatant fractions of bacterial cell sonicates of various Helicobacter spp. varied according to which Helicobacter spp. fraction was used (Fig. 4A-D). Supernatant fractions of sonicates from both $H$. pylori strains that lacked the gene for $\mathrm{CdtB}$ did not affect the morphology of HeLa cells. Cells treated with the Cdt toxin of the positive control strain $C$. jejuni 81-176 became distended and the nuclei were larger than those in control cells (Fig. 4B). Many cells were multinucleate and some cells appeared to be undergoing nuclear fragmentation. The effect of supernatant fractions of cell sonicates from $H$. hepaticus (Fig. 4C) and Helicobacter sp. strain 98-6070 (data not shown) caused morphological changes in $>80 \%$ of HeLa cells; these results were similar to those obtained with $C$. jejuni strain 81-176, the positive control (Fig. 4B). $H$. canis caused changes in $\sim 40 \%$ of the HeLa cells (Fig. 4D). The preparation from $H$. bilis showed similar cytodistending effects in $10-15 \%$ of the HeLa cells, whereas the supernatant fraction of sonicates of Helicobacter sp. strain 96-1001 had no effect on the HeLa cells.

\section{Cell cycle arrest in $G_{2} / M$}

Filter-sterilised supernatant fractions of cell sonicates of six species of Helicobacter were examined for their ability to block cell cycle progression by analysing HeLa cell DNA content by flow cytometry (Fig. 5). Sub-confluent HeLa cells were treated with the supernatant fractions of cell sonicates for $72 \mathrm{~h}$. The cytolethal distending toxin in the positive control strain of C. jejuni (81-176) caused $54.8 \%$ of the cells to become arrested in $\mathrm{G}_{2} / \mathrm{M}$ compared with only $6.9 \%$ of control cells treated with PBS. The preparations from H. pylori and the novel urease-negative Helicobacter sp. strain 96-1001 gave results similar to those of the control. The fractions from H. hepaticus and Helico-

Table 1. Similarity matrix based on the nucleotide sequences of partial $c d t B^{*}$

\begin{tabular}{|c|c|c|c|c|c|c|c|c|c|c|}
\hline \multirow[b]{2}{*}{ Organism } & \multicolumn{10}{|c|}{ Percentage similarity with } \\
\hline & (1) & (2) & (3) & (4) & (5) & (6) & (7) & (8) & (9) & (10) \\
\hline (1) H. hepaticus & $\ldots$ & 69.6 & 68.9 & 59.4 & 59.3 & 57.0 & 53.9 & 55.4 & 59.5 & 57.3 \\
\hline (2) H. bilis & & $\ldots$ & 75.3 & 56.7 & 58.1 & 53.6 & 54.5 & 53.5 & 60.4 & 54.7 \\
\hline (3) H. canis & & & $\ldots$ & 57.1 & 58.9 & 53.6 & 52.3 & 53.6 & 58.3 & 54.4 \\
\hline (4) Helicobacter 96-1001 & & & & $\ldots$ & 69.2 & 58.4 & 55.2 & 57.1 & 64.0 & 58.1 \\
\hline (5) Helicobacter 98-6070 & & & & & $\ldots$ & 53.4 & 54.9 & 57.8 & 64.8 & 52.7 \\
\hline (6) $H$. ducreyi & & & & & & $\ldots$ & 51.1 & 54.3 & 58.0 & 95.8 \\
\hline (7) $E \cdot$ coli $^{\dagger}$ & & & & & & & $\ldots$ & 56.2 & 54.1 & 52.0 \\
\hline (8) E. coli* & & & & & & & & $\ldots$ & 60.8 & 54.2 \\
\hline (9) C. jejuni & & & & & & & & & $\ldots$ & 57.0 \\
\hline (10) A. actinomycetemcomitans & & & & & & & & & & $\ldots$ \\
\hline
\end{tabular}

\footnotetext{
*Alignment done by Jotun Hein Method [40] included in Lasergene software (DNASTAR, Madison, WI, USA).

†Sequence from Scott and Kaper [27].
}

tSequence from Pickett et al. [26]. 
C. jejunicdtB M K K I I C L F L S F N L A F A N L E N F N V G T W N L Q

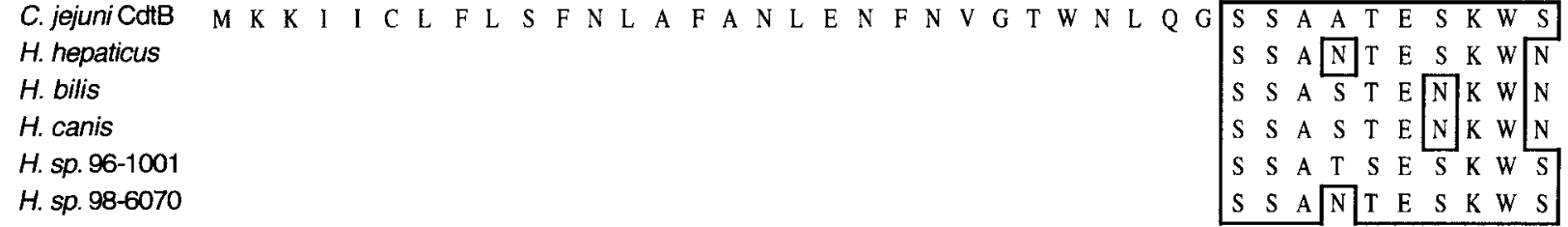

C. jejuni CdtB H. hepaticus

H. bilis

H. canis

H. sp. 96-1001

H. sp. $98-6070$

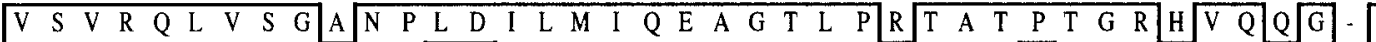

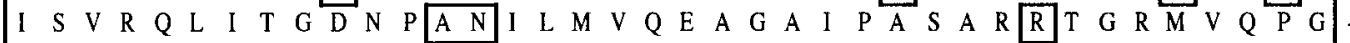

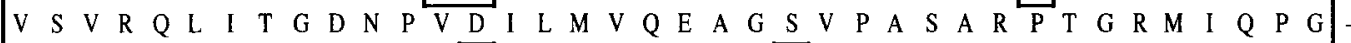

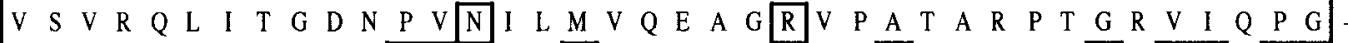

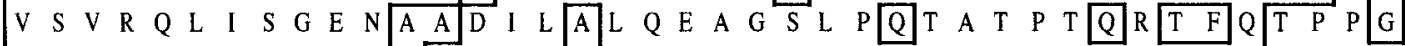

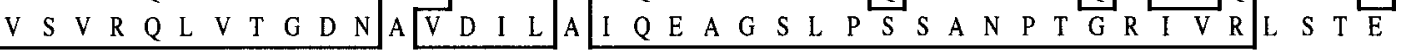

C. jejuni CdtB H. hepaticus H. bilis

H. canis H. sp. 96-1001 H. sp. $98-6070$

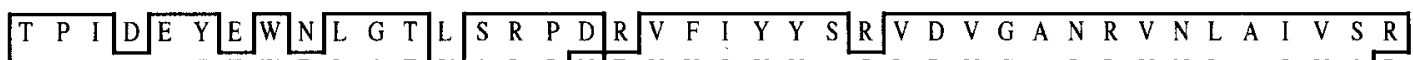

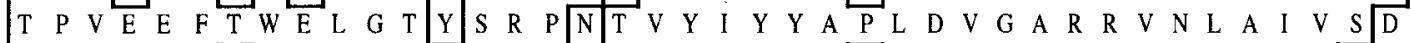

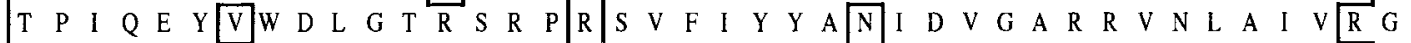
$\begin{array}{lllllllllllllllllllllllllllllllllllllllll}T & P & I & E & E & Y & T & W & D & L & G & T & R & S & R & P & N & S & V & F & I & Y & Y & A & N & I & D & V & G & A & R & R & V & N & M & A & I & V & S & A\end{array}$ \begin{tabular}{llllllllllllllllllllllllllllllllllllllll}
$I$ & $P$ & $I$ & $A$ & $E$ & $Y$ & $T$ & $W$ & $D$ & $L$ & $G$ & $S$ & $R$ & $S$ & $R$ & $P$ & $D$ & $M$ & $V$ & $Y$ & $I$ & $Y$ & $Y$ & $S$ & $P$ & $V$ & $D$ & $V$ & $G$ & $A$ & $N$ & $R$ & $V$ & $N$ & $L$ & $A$ & $I$ & $V$ & $S$ & $R$ \\
\hline
\end{tabular}

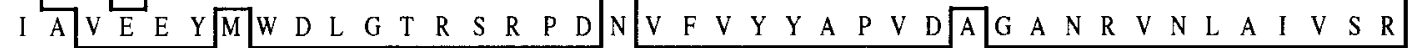

C. jejuni CdtB H. hepaticus H. bilis H. canis H. sp. 96-1001 H. sp. $98-6070$

C. jejuni CdtB H. hepaticus H. bilis

H. canis H. sp. 96-1001 H. $s p .98-6070$
$M \longdiv { Q }$ A E E E V I V L P

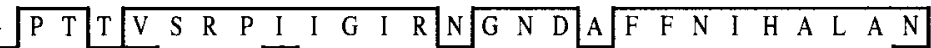

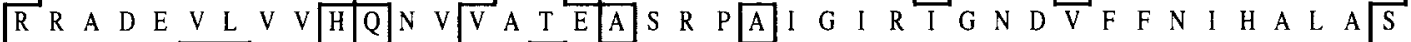

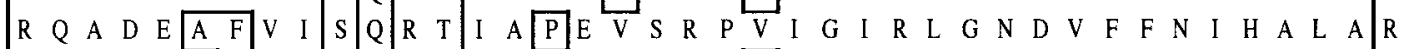
$\begin{array}{lllllllllllllllllllllllllllllllllllllll}R & Q & A & E & E & V & F & V & I & R & Q & D & R & I & A & A & D & V & S & R & P & A & I & G & I & R & I & G & N & D & V & F & F & N & I & H & A & L & A\end{array}$ R M A

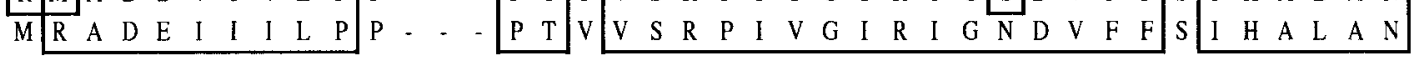

C. jejuni CdtB H. hepaticus H. bilis

H. canis

H. sp. $96-1001$

H. sp. $98-6070$

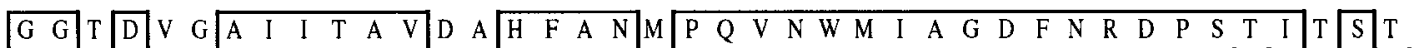

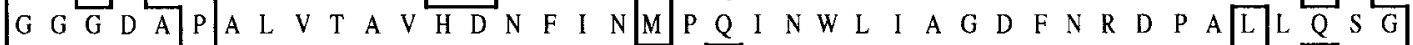

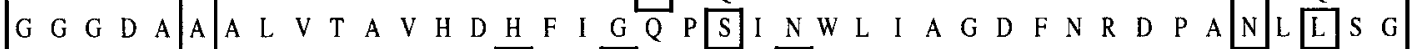

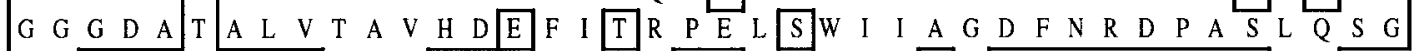

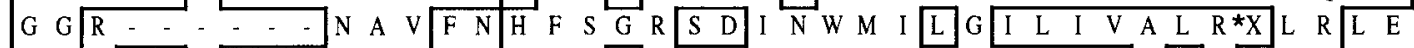

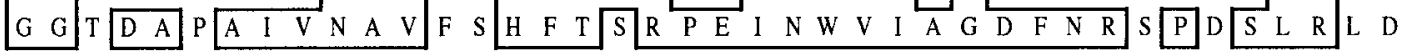

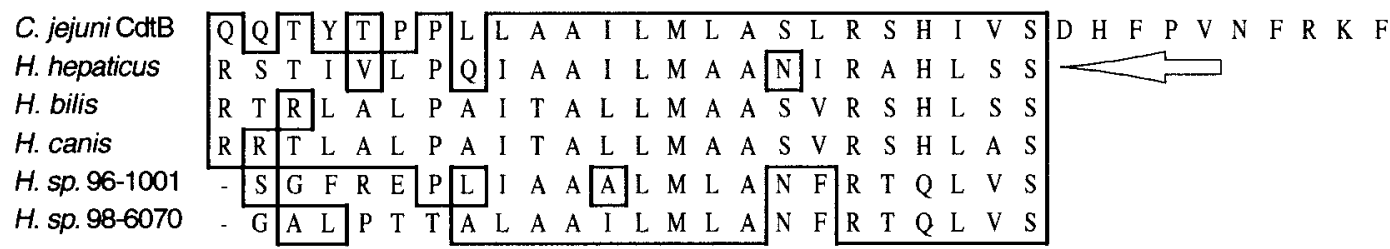

Fig. 1. Comparison of the predicted amino-acid sequences of $\mathrm{CdtB}$ proteins from C. jejuni, H. hepaticus, H. bilis, H. canis, Helicobacter spp. strain 96-1001 and strain 98-6070. The sequences of the primer regions are underlined with open arrows. Regions of similarity are in the enclosed boxes. In Helicobacter sp. strain 96-1001, there was a single base deletion in the codon for amino acid 157 that created a frameshift which resulted in a premature termination. A nucleotide $\mathrm{N}$ was inserted in the third position of the amino acid $157\left(^{*} \mathrm{X}\right)$ of Helicobacter sp. strain $96-1001$ to correct for the frameshift mutation, allowing completion of the sequence. 

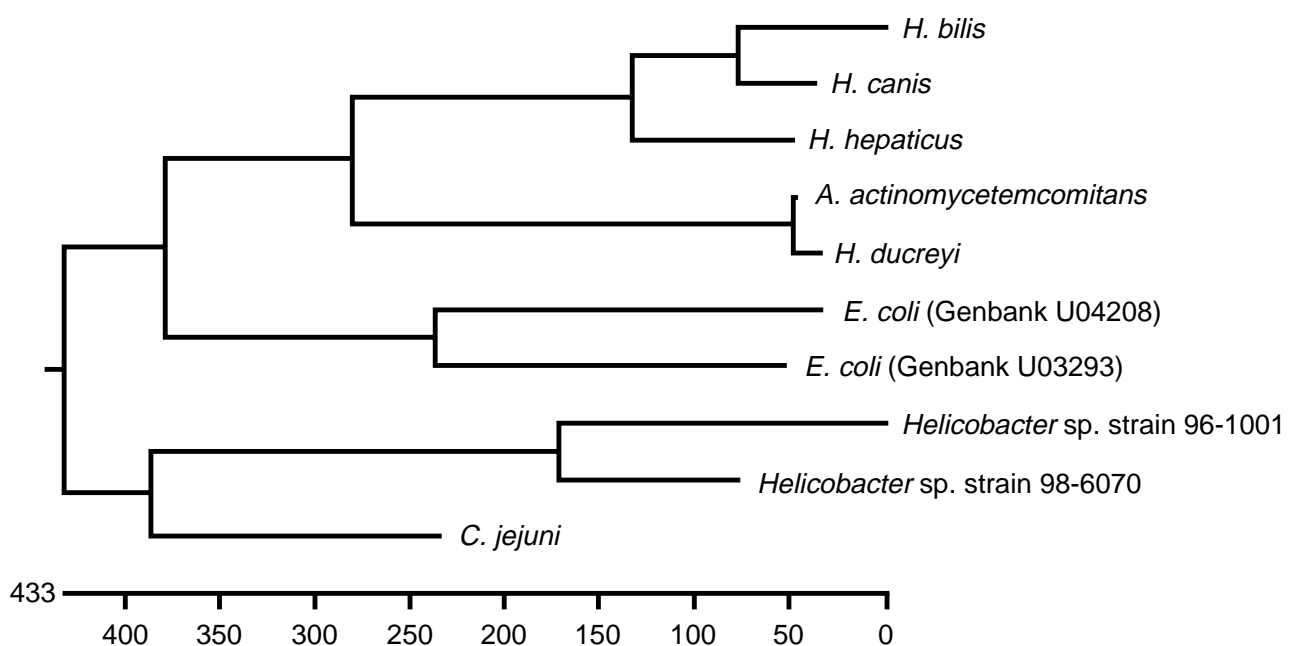

Fig. 2. Phylogenetic relationship of CdtB proteins between C. jejuni, E. coli, H. ducreyi, A. actinomycetemcomitans, H. hepaticus, H. bilis, H. canis, Helicobacter spp. strain 96-1001 and strain 98-6070. The alignment was done by the method described by Hein [39] included in Lasergene software (DNASTAR). The length of each pair of branches represents the distance between the respective CdtB sequence pairs. The scale beneath the tree measures the distance between the CdtB sequences. Units indicate the number of substitution events.

a

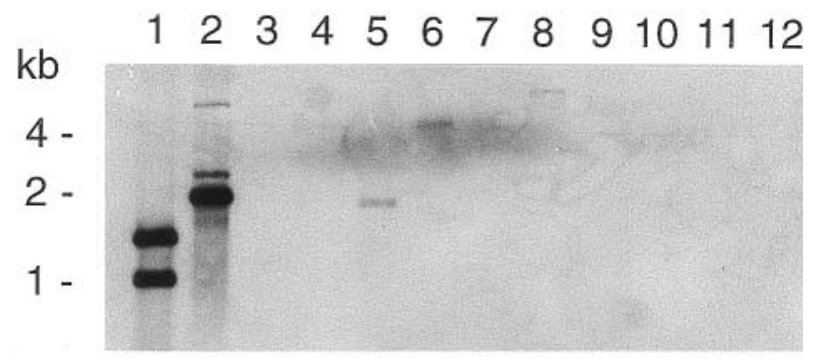

b
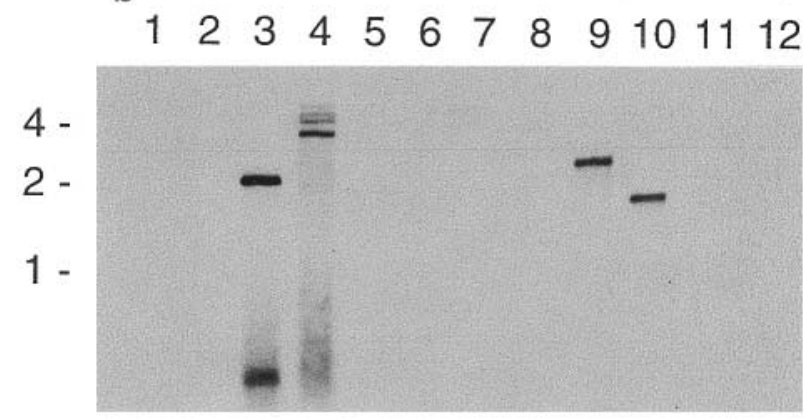

Fig. 3. Southern hybridisation with probes prepared from $c d t B$ genes of Helicobacter spp. Restriction endonucleases used to digest DNA in each lane: lanes 1, 3, 5, 7, 9 and 11: Ase I; lanes 2, 4, 6, 8, 10, 12: HindIII. Lanes 1 and 2, H. hepaticus; 3 and 4, Helicobacter sp. strain $96-1001 ; 5$ and $\mathbf{6}, H$ bilis; 7 and $\mathbf{8}, H$. canis; 9 and 10, Helicobacter sp. strain 98-6070; 11 and 12, $H$. pylori. (a) Results with the $H$. hepaticus $c d t B$ gene probe. The probe hybridised with genomic DNA of $H$. hepaticus (lanes 1 and 2) and weakly hybridised with $H$. bilis (5 and 6) and $H$. canis (8). There is no hybridisation signal of the lane 7 , probably because $H$. canis DNA could not be completely digested by Ase I. (b) The same membrane with a $c d t B$ gene probe from Helicobacter sp. strain 96-1001. The probe hybridised with genomic DNA of Helicobacter spp. strain 96-1001 (lanes 3 and 4) and strain 98-6070 (9 and 10), but not with $H$. hepaticus, $H$. bilis and $H$. canis. Neither probe hybridised with $H$. pylori DNA (11 and 12). bacter sp. strain $98-6070$ resulted in $61.6 \%$ and $45.4 \%$ of the HeLa cells being arrested in $\mathrm{G}_{2} / \mathrm{M}$, respectively. $H$. bilis and $H$. canis supernatant fractions also blocked cell cycle progression in $\mathrm{G}_{2} / \mathrm{M}$ phase, although their effects were lower than those obtained with the Cdt proteins of C. jejuni, H. hepaticus and Helicobacter sp. 98-6070. Table 2 summarises the ability of supernatant fractions of sonicates of different Helicobacter spp. to block HeLa cell cycle in $\mathrm{G}_{2} / \mathrm{M}$ as measured by flow cytometry.

\section{Discussion}

There is accumulating evidence that many enterohepatic Helicobacter spp. play an important, pathogenic role in gastrointestinal and hepatic diseases in man and animals $[17,19,21]$. This includes the ability of $H$. hepaticus to cause hepatitis and hepatocellular carcinoma in susceptible strains of mice $[6,7,41,42]$. The increased apoptosis noted in male $\mathrm{B}_{6} \mathrm{C}_{3} \mathrm{~F}_{1}$ mice with chronic hepatitis in part may be due to the presence of persistent hepatic infection with $H$. hepaticus and chronic exposure to Cdt [43]. H. hepaticus is also directly linked with naturally occurring as well as experimentally produced IBD in a variety of immune dysregulated mice [9-11,44]. Interestingly, the other helicobacters thus far shown to produce Cdt, i.e., $H$. bilis, H. canis, H. pullorum, also cause hepatitis and have been associated with diarrhoea in their respective hosts [35].

The demonstration of the $c d t$ homologues in many novel enterohepatic Helicobacter spp. confirms and extends the preliminary finding of $c d t$ in $H$. hepaticus and H. pullorum [35]. The discovery of $\mathrm{Cdt}$ in enteropathogenic helicobacters may help clarify the pathogenic potential of different Helicobacter spp. Cdt 


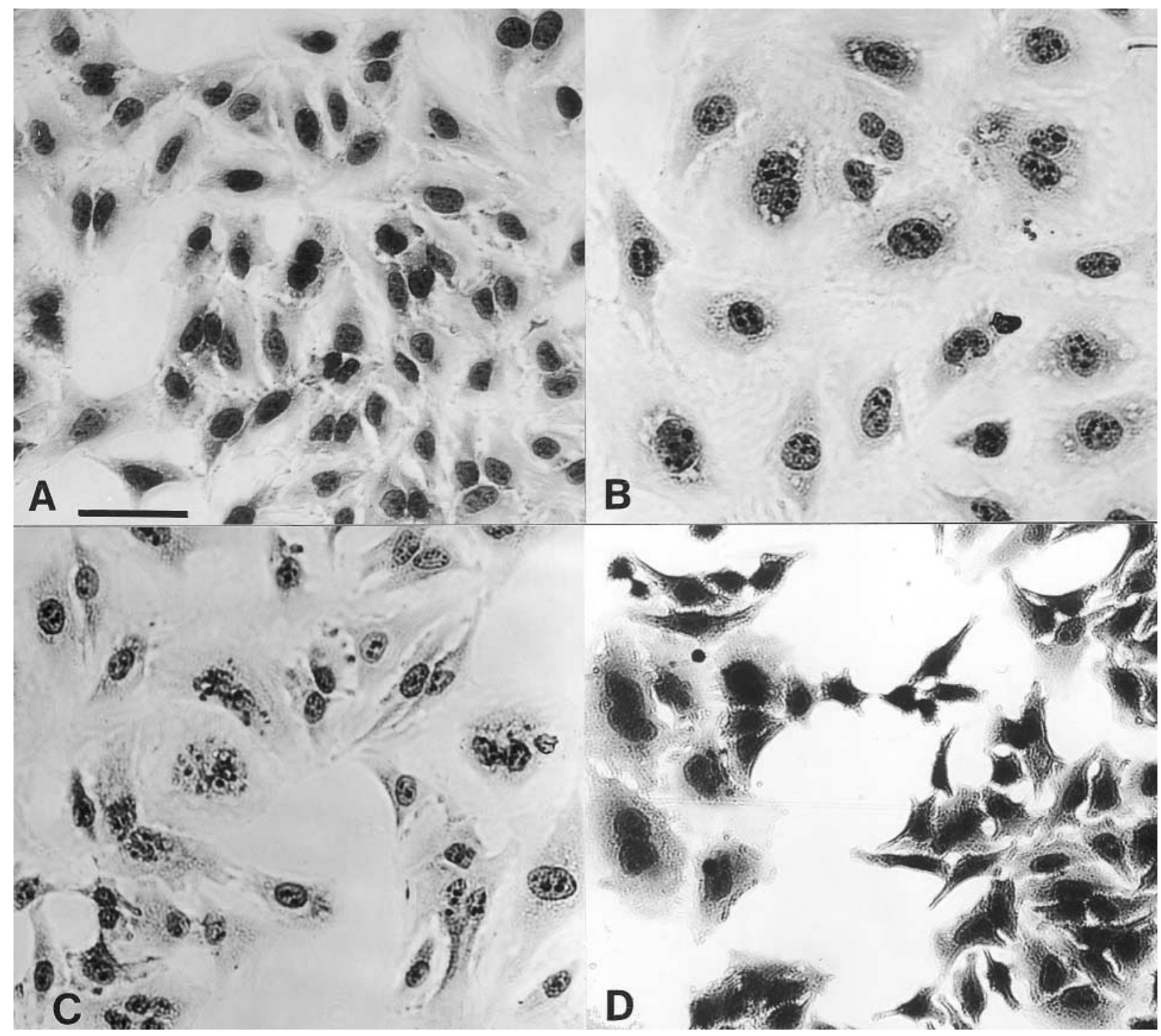

Fig. 4. Giemsa-stained HeLa cells exposed for $72 \mathrm{~h}$ to filter-sterilised supernatant fractions of cell sonicates of $H$. pylori (a), C. jejuni strain 81-176 (b), H. hepaticus (c) and H. canis (d). C. jejuni, H. hepaticus, H. canis and Helicobacter sp. strain 98-6070 (not shown) induced the formation of giant, mono- and multi-nucleated cells with large nuclei. $\operatorname{Bar}=75 \mu \mathrm{m}$.

is believed to play a role in producing diarrhoea in human patients infected with enteric pathogens such as C. jejuni, E. coli and S. dysenteriae. Bacteria that produce Cdt, like many other bacterial pathogens, produce more than one toxin that may contribute to their pathogenesis. For example, heat-labile (LT) enterotoxin and cytotoxic necrotising factors may also be present in E. coli which has Cdt [22, 28]. H. ducreyi elaborates other toxins in addition to $\mathrm{Cdt}$, including haemolysin and a cytotoxin $[45,46]$. H. hepaticus also has another toxin that causes granulation in a mouse hepatic cell line that is distinct from the cytopathogenic effect of Cdt [47]. The two toxins differ in at least two ways: first, the granulating cytotoxin is stable at $56^{\circ} \mathrm{C}$ for $30 \mathrm{~min}$, whereas $\mathrm{Cdt}$ is heat-labile [22, 23, 47]; and second, $H$. hepaticus polyclonal antibody is able to neutralise the $H$. hepaticus $\mathrm{Cdt}$ toxin activity on HeLa cells, but does not neutralise the granulating cytotoxin activity on mouse hepatic cells (data not shown). Thus,
$\mathrm{Cdt}$ in $H$. hepaticus, like $\mathrm{Cdt}$ in other bacterial pathogens, may function in concert with other purported virulence factors $[30,31]$.

The partial $c d t B$ sequences of several enterohepatic Helicobacter spp. indicate that the gene, similar to that described for Campylobacter spp., has a distinct divergence among species. In the genus Campylobacter, the probe prepared from the $c d t B$ gene of $C$. jejuni failed to hybridise or only weakly hybridised to the DNA of C. fetus, C. hyointestinalis, $C$. laris and $C$. coli [24]. Because of the divergence of this gene, use of selected degenerative primers may not always amplify the desired $c d t B$ fragment from species that possess the $c d t$ gene. For example, PCR did not produce the expected amplicon from $H$. bilis with the primers described by Pickett et al. [24], but it was possible to obtain the amplicon with the primers designed in the present study. Additional degenerative 

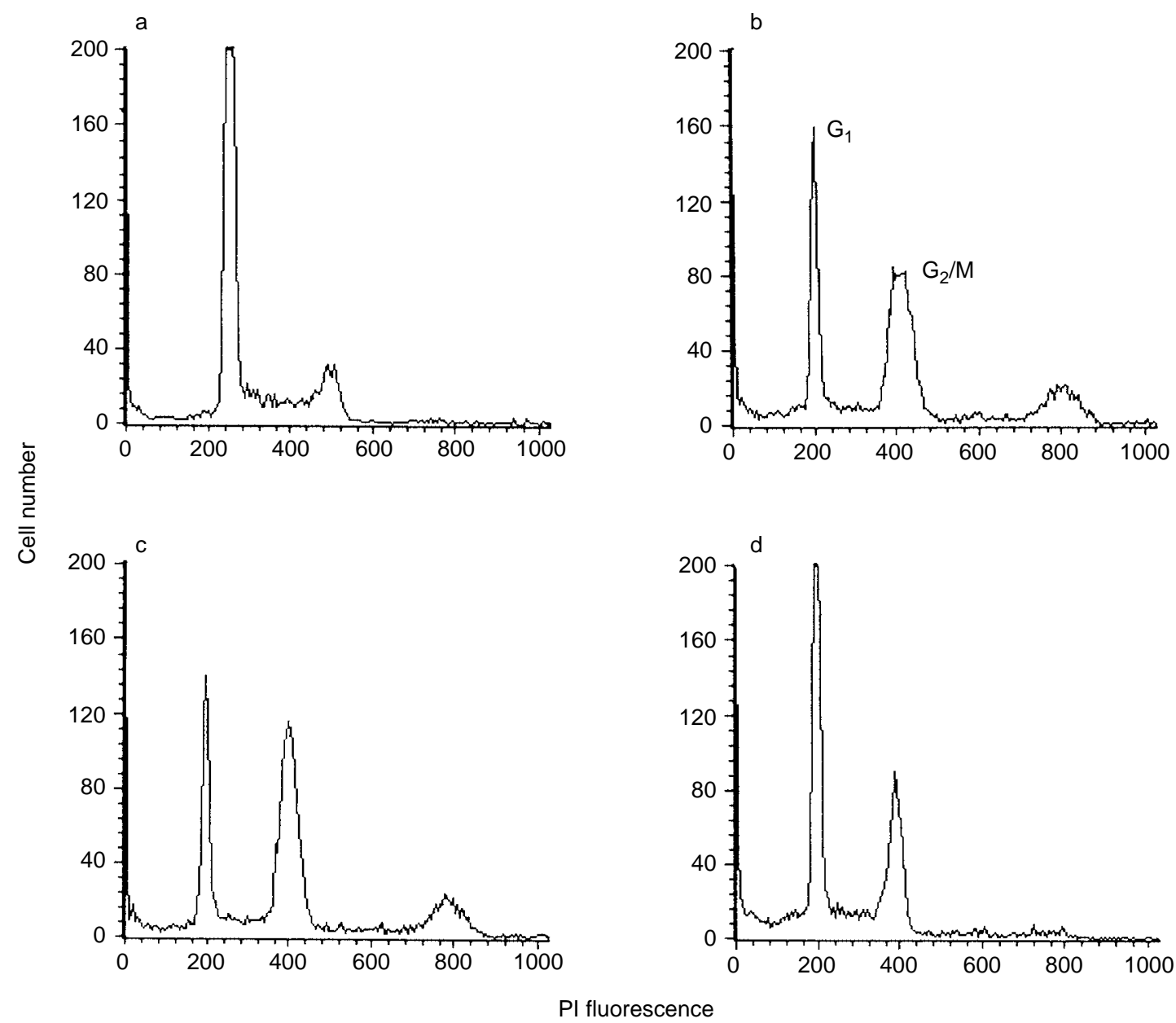

Fig. 5. DNA content of HeLa cells analysed by flow cytometry and propidium iodide fluorescence. HeLa cells were exposed for $72 \mathrm{~h}$ to (a) phosphate-buffered saline (control) or bacterial cell sonicates. Compared with control cells, HeLa cells exposed to (b) C. jejuni, (c) H. hepaticus and (d) H. canis cell sonicates showed an increase in the number of cells with $4 \mathrm{~N}$ DNA content. The novel Helicobacter sp. strain 98-6070 from the woodchuck had a response similar to H. hepaticus; and H. pylori and the murine isolate (Helicobacter sp. strain 96-1001) were identical to control cells (data not shown).

Table 2. DNA content analyses of HeLa cell cultures treated with filter-sterilised supernatant fractions of bacterial cell sonicates of $C$. jejuni and different Helicobacter spp.

\begin{tabular}{lccc}
\hline & \multicolumn{3}{c}{ Percentage of sample that were in } \\
\cline { 2 - 4 } Organism & $\mathrm{G}_{0} / \mathrm{G}_{1}$ phase & $\mathrm{G}_{2} / \mathrm{M}$ phase & S phase \\
\hline Control (PBS) & 72.5 & 6.9 & 20.6 \\
C. jejuni & 34 & 54.8 & 11.2 \\
H. hepaticus & 28.3 & 61.6 & 10.1 \\
Helicobacter sp. strain $98-6070$ & 36.1 & 45.4 & 18.5 \\
H. canis & 55.8 & 28.3 & 15.9 \\
H. bilis & 65.7 & 18.9 & 15.4 \\
Helicobacter sp. strain $96-1001$ & 72.7 & 7.2 & 20.1 \\
H. pylori & 71.5 & 7.8 & 20.7 \\
\hline
\end{tabular}

PCR primers from various conserved regions are needed to evaluate the presence or absence of the $c d t$ homologue in the growing number of novel Helicobacter spp. as well as other bacterial pathogens.

An unusually high percentage amino-acid sequence identity (99\%) between $S$. dysenteriae Cdt and E. coli
Cdt-I has been reported by Okuda et al. [27, 48]. Also, the amino-acid sequences of the Cdt produced by $H$. ducreyi and A. actinomycetemcomitans share a high degree of similarity $(91 \%, 97 \%$ and $94 \%$ in CdtA, $\mathrm{CdtB}$ and $\mathrm{CdtC}$, respectively) [31]. Evolutionarily, these two bacteria are closely related, suggesting that their $c d t$ genes could have originated from the same 
ancestral gene [31]. Although the sequences of the Cdt in enterohepatic Helicobacter spp. do not share this high degree of similarity, the results of the present study still suggest that CdtB proteins of $H$. hepaticus, $H$. bilis and $H$. canis are more closely related to each other than to the CdtB homologues of other bacteria (Fig. 2). 16S rRNA phylogenic analysis also indicates that these three species of Helicobacter are closely related [21].

The complete genomic DNA sequences from two different strains of $H$. pylori indicate that the $c d t$ gene is absent from this gastric pathogen $[49,50]$. Attempts to amplify a $c d t$ homologue with degenerative PCR primers from $H$. pylori and another gastric helicobacter, H. mustelae, were also unsuccessful (unpublished data). Whether the absence of the $c d t$ gene is also a feature of other gastric Helicobacter spp. will require further investigation. The primers used in this study also failed to produce the expected size of amplicon from another intestinal helicobacter ' $H$. rappini' (ATCC 43879) (results not shown), which supports the recent finding that the $\mathrm{CdtB}$ homologue is not present in all Helicobacter species [35].

Filter-sterilised supernatant fractions from whole-cell lysates of four of five Helicobacter spp. caused morphological alterations in HeLa cells and blocked the cell cycle in $\mathrm{G}_{2} / \mathrm{M}$. These data further confirm the presence of $c d t$ homologues in these enterohepatic Helicobacter spp. H. bilis possessed significantly lower activity despite the presence of the toxin genes. Other authors have also noted a wide variability in the amount of toxin produced in different strains of $C$. jejuni as well as C. coli [24]. A recent study of 70 strains of $C$. jejuni isolated from poultry indicated that $100 \%$ of the strains had $c d t$ genes; however, one strain failed to produce a Cdt-induced cytopathology on HeLa cells. The authors suggested that this strain might have a mutation in the $c d t B$ gene that rendered it incapable of producing the toxin [51]. There was a single base deletion in the $c d t B$ gene of Helicobacter sp. strain 961001 that may have caused the protein to be truncated (Fig. 1), accounting for the lack of detectable toxin activity in this bacterium. Further investigation, including determination of the full sequences of $c d t A$ and $c d t C$ genes and direct cloning of the toxin gene from genomic DNA instead of determining the sequence by PCR, will be necessary to fully explore this hypothesis.

S. dysenteriae Cdt is capable of causing diarrhoea with colonic erosions and reparative enterocyte hyperplasia in suckling mice [48]; the presence of $\mathrm{Cdt}$ in enterohepatic Helicobacter spp. suggests that this toxin may also be associated with the ability of these bacteria to interact with host enterocytes and intestinal inflammatory cells and play a role in intestinal disease. This laboratory is continuing to screen other novel helicobacters for the presence of $c d t$ homologues to help determine if this toxin might play a role in the pathogenesis of hepatobiliary as well as gastrointestinal disease produced by this genus. Studies also are underway in this laboratory to purify the Helicobacter Cdt toxin, to clone and identify the genes that encode the toxin and to construct isogenic Helicobacter mutants that lack Cdt. These isogenic mutants could then be used for pathogenesis studies in vivo. It is hoped that characterisation of $\mathrm{Cdt}$ in Helicobacter species as well as targeted development of in-vivo pathogenesis models will help to elucidate the hostpathogen relationships of helicobacter infection in a variety of animal hosts.

This work was supported in part by NIH grants R01CA67529, RO1CA26731, RR010146 and R01DK52413.

\section{References}

1. Graham DY. Campylobacter pylori and peptic ulcer disease. Gastroenterology 1989; 96: 615-625.

2. Lee A, Fox, J, Hazell S. Pathogenicity of Helicobacter pylori: a perspective. Infect Immun 1993; 61: 1601-1610.

3. Nomura A, Stemmermann GN, Chyou P-H, Kato I, Perez-Perez GI, Blaser MJ. Helicobacter pylori infection and gastric carcinoma among Japanese Americans in Hawaii. $N$ Engl $J$ Med 1991; 325: 1132-1136.

4. Parsonnet J, Friedman GD, Vandersteen DP et al. Helicobacter pylori infection and the risk of gastric carcinoma. $N$ Engl $J$ Med 1991; 325: 1127-1131.

5. Parsonnet J, Hanson S, Rodriguez L et al. Helicobacter pylori infection and gastric lymphoma. Engl J Med 1994; 330: 1267-1271

6. Fox JG, Dewhirst FE, Tully JG et al. Helicobacter hepaticus sp. nov., a microaerophilic bacterium isolated from livers and intestinal mucosal scrapings from mice. J Clin Microbiol 1994; 32: $1238-1245$.

7. Ward JM, Fox JG, Anver MR et al. Chronic active hepatitis and associated liver tumors in mice caused by persistent bacterial infection with a novel Helicobacter species. $J$ Natl Cancer Inst 1994; 86: 1222-1227.

8. Fox JG, Yan LL, Dewhirst FE et al. Helicobacter bilis sp. nov., a novel Helicobacter species isolated from bile, livers, and intestines of aged, inbred mice. J Clin Microbiol 1995; 33: $445-454$.

9. Ward JM, Anver MR, Haines DC et al. Inflammatory large bowel disease in immunodeficient mice naturally infected with Helicobacter hepaticus. Lab Anim Sci 1996; 46: 15-20.

10. Cahill RJ, Foltz CJ, Fox JG, Dangler CA, Powrie F, Schauer DB. Inflammatory bowel disease: an immunity mediated condition triggered by bacterial infection with Helicobacter hepaticus. Infect Immun 1997; 65: 3126-3131.

11. Foltz CJ, Fox JG, Cahill RJ et al. Spontaneous inflammatory bowel disease in multiple mutant mouse lines: association with colonization by Helicobacter hepaticus. Helicobacter 1998; 3: $69-78$.

12. Shomer NH, Dangler CA, Marini R, Fox JG. Helicobacter bilis/Helicobacter rodentium co-infection associated with diarrhoea in a colony of scid mice. Lab Anim Sci 1998; 48: $455-459$.

13. Whary MT, Morgan TJ, Dangler CA, Gaudes KJ, Taylor NS, Fox JG. Chronic active hepatitis induced by Helicobacter hepaticus in the A/JCr mouse is associated with a Th1 cellmediated immune response. Infect Immun 1998; 66: 31423148.

14. Fox JG, Gorelick PL, Kullberg MC, Ge Z, Dewhirst FE, Ward JM. A novel urease-negative Helicobacter species associated with colitis and typhlitis in IL-10-deficient mice. Infect Immun 1999; 67: 1757-1762.

15. Saunders KE, Shen Z, Dewhirst FE, Paster BJ, Dangler CA, Fox JG. Novel intestinal Helicobacter species isolated from cotton-top tamarins (Saguinus oedipus) with chronic colitis. $J$ Clin Microbiol 1999; 37: 146-151.

16. Totten PA, Fennell CL, Tenover FC. Campylobacter cinaed (sp. 
nov.) and Campylobacter fennelliae (sp. nov.): two new Campylobacter species associated with enteric disease in homosexual men. J Infect Dis 1985; 151: 131-139.

17. Burnens AP, Stanley J, Schaad UB, Nicolet J. Novel Campylobacter-like organism resembling Helicobacter fennelliae isolated from a boy with gastroenteritis and from dogs. J Clin Microbiol 1993; 31: 1916-1917.

18. Fox JG, Drolet R, Higgins R et al. Helicobacter canis isolated from a dog liver with multifocal necrotizing hepatitis. J Clin Microbiol 1996; 34: 2479-2482.

19. Fox JG, Lee A. The role of Helicobacter species in newly recognized gastrointestinal tract diseases of animals. Lab Anim Sci 1997; 47: 222-255.

20. Fox JG, Yu S, Dangler CA, Cullen JM. A novel Helicobacter sp. isolated from woodchuck livers infected with woodchuck hepatitis virus (WHV). Gastroenterology 1999; 116: A718 (Abstract G3116).

21. Fox JG, Dewhirst FE, Shen Z et al. Hepatic Helicobacter species identified in bile and gallbladder tissue from Chileans with chronic cholecystitis. Gastroenterology 1998; 114: 755763

22. Johnson WM, Lior H. Response of Chinese hamster ovary cells to a cytolethal distending toxin (CDT) of Escherichia coli and possible misinterpretation as heat-labile (LB) enterotoxin. FEMS Microbiol Lett 1987; 43: 19-23.

23. Johnson WM, Lior H. A new heat-labile cytolethal distending toxin (CLDT) produced by Campylobacter spp. Microb Pathog 1988; 4: 115-126.

24. Pickett CL, Pesci EC, Cottle DL, Russell G, Erdem AN, Zeytin H. Prevalence of cytolethal distending toxin production in Campylobacter jejuni and relatedness of Campylobacter sp. cdtB genes. Infect Immun 1996; 64: 2070-2078.

25. Bouzari S, Varghese A. Cytolethal distending toxin (CLDT) production by enteropathogenic Escherichia coli (EPEC). FEMS Microbiol Lett 1990; 71: 193-198.

26. Pickett CL, Cottle DL, Pesci EC, Bikah G. Cloning, sequencing, and expression of the Escherichia coli cytolethal distending toxin genes. Infect Immun 1994; 62: 1046-1051.

27. Scott DA, Kaper JB. Cloning and sequencing of the genes encoding Escherichia coli cytolethal distending toxin. Infect Immun 1994; 62: 244-251.

28. Pérès SY, Marchès $\mathrm{O}$, Daigle $\mathrm{F}$ et al. A new cytolethal distending toxin (CDT) from Escherichia coli producing CNF2 blocks HeLa cell division in $\mathrm{G} 2 / \mathrm{M}$ phase. Mol Microbiol 1997; 24: 1095-1107.

29. Okuda J, Kurazono H, Takeda Y. Distribution of the cytoletha distending toxin A gene ( $c d t A)$ among species of Shigella and Vibrio, and cloning and sequencing of the $c d t$ gene from Shigella dysenteriae. Microb Pathog 1995; 18: 167-172.

30. Cope LD, Lumbley S, Latimer JL et al. A diffusible cytotoxin of Haemophilus ducreyi. Proc Natl Acad Sci USA 1997; 94: 4056-4061.

31. Sugai M, Kawamoto T, Pérès SY et al. A cell cycle-specific growth-inhibitory factor produced by Actinobacillus actinomycetemcomitans is a cytolethal distending toxin. Infect Immun 1998; 66: 5008-5019.

32. Mayer MPA, Bueno LC, Hansen EJ, DiRienzo JM. Identification of a cytolethal distending toxin gene locus and features of a virulence-associated region in Actinobacillus actinomycetemocomitans. Infect Immun 1999; 67: 1227-1237.

33. Comayras C, Tasca C, Pérès SY, Ducommun B, Oswald E, De Rycke J. Escherichia coli cytolethal distending toxin blocks the HeLa cell cycle at the $G_{2} / M$ transition by preventing cdc2 protein kinase dephosphorylation and activation. Infect Immun 1997; 65: 5088-5095.

34. Whitehouse CA, Balbo PB, Pesci EC, Cottle DL, Mirabito PM,
Picket CL. Campylobacter jejuni cytolethal distending toxin causes a $\mathrm{G}_{2}$-phase cell cycle block. Infect Immun 1998; 66: 1934-1940.

35. Young VB, Schauer DB. Identification and characterization of cytolethal distending toxin (CDT) activity in enterohepatic Helicobacter species (abstract). American Society for Microbiology General Meeting 1999; 208/D/B/: D/B-184.

36. Stanley J, Linton D, Burrens AP et al. Helicobacter canis sp. nov., a new species from dogs: an integrated study of phenotype and genotype. J Gen Microbiol 1993; 139: 24952504.

37. Black RE, Levine MM, Clements ML, Hughes TP, Blaser MJ. Experimental Campylobacter jejuni infection in humans. J Infect Dis 1988; 157: 472-479.

38. Shomer NH, Dangler CA, Schrenzel MD, Fox JG. A novel urease-negative intestinal Helicobacter species causes severe proliferative typhlocolitis in scid mice with defined flora (abstract). Lab Anim Sci 1998; 48: 408.

39. Birnboim HC, Doly JA. Rapid alkaline extraction procedure for screening recombinant plasmid DNA. Nucleic Acids Res 1979; 7: 1513-1523.

40. Hein J. Unified approach to alignment and phylogenies. In: Doolittle RF (ed) Molecular evolution: computer analysis of protein and nucleic acid sequences. Methods in enzymology 183. San Diego, Academic Press. 1990: 626-645.

41. Fox JG, Li X, Yan L et al. Chronic proliferative hepatitis in A/JCr mice associated with persistent Helicobacter hepaticus infection: a model of helicobacter-induced carcinogenesis. Infect Immun 1996; 64: 1548-1558.

42. Hailey JR, Haseman JK, Bucher JR et al. Impact of Helicobacter hepaticus infection in $\mathrm{B} 6 \mathrm{C} 3 \mathrm{~F} 1$ mice from twelve National Toxicology Program two-year carcinogenesis studies. Toxicol Pathol 1998; 26: 602-611.

43. Nyska A, Maronpot RR, Eldridge SR, Haseman JK, Hailey JR. Alteration in cell kinetics in control B6C3F1 mice infected with Helicobacter hepaticus. Toxicol Pathol 1997; 25: 591596.

44. Kullberg MC, Ward JM, Gorelick PL et al. Helicobacter hepaticus triggers colitis in specific-pathogen-free interleukin10 (IL-10)-deficient mice through an IL-12 - and gamma interferon-dependent mechanism. Infect Immun 1998; 66: 5157-5166.

45. Palmer KL, Grass S, Munson RS. Identification of a hemolytic activity elaborated by Haemophilus ducreyi. Infect Immun 1994; 62: 3041-3043.

46. Purvén M, Frisk A, Lönnroth I, Lagergård T. Purification and identification of Haemophilus ducreyi cytotoxin by use of a neutralizing monoclonal antibody. Infect Immun 1997; 65: 3496-3499.

47. Taylor NS, Fox JG, Yan L. In-vitro hepatotoxic factor in Helicobacter hepaticus, $H$. pylori and other Helicobacter species. J Med Microbiol 1995; 42: 48-52.

48. Okuda J, Fukumoto M, Takeda Y, Nishibuchi M. Examination of diarrheagenicity of cytolethal distending toxin: suckling mouse response to the products of the cdtABC genes of Shigella dysenteriae. Infect Immun 1997; 65: 428-433.

49. Tomb JF, White O, Kerlavage AR et al. The complete genome sequence of the gastric pathogen Helicobacter pylori. Nature 1997; 388: 539-547.

50. Alm RA, Ling L-SL, Moir DT et al. Genomic-sequence comparison of two unrelated isolates of the human gastric pathogen Helicobacter pylori. Nature 1999; 397: 176-180.

51. Eyigor A, Dawson KA. Langlois BE, Pickett CL. Detection of cytolethal distending toxin activity and cdt genes in Campylobacter spp. isolated from chicken carcasses. Appl Environ Microbiol 1999; 65: 1501-1505. 